\title{
The Impact of Current Climate Changes on Morphodynamic Regimes of Steppes and Forest Steppes in Southern Siberia
}

\author{
Olga Bazhenova1, Elizaveta Tyumentseva ${ }^{2}$ \\ ${ }^{1}$ V.B. Sochava Institute of Geography SB RAS, Irkutsk, Russia \\ ${ }^{2}$ Irkutsk State University, Irkutsk, Russia \\ Email: cherryoghurt@yandex.ru
}

How to cite this paper: Bazhenova, O., \& Tyumentseva, E. (2021). The Impact of Current Climate Changes on Morphodynamic Regimes of Steppes and Forest Steppes in Southern Siberia. American Journal of Climate Change, 10, 317-330. https://doi.org/10.4236/ajcc.2021.103015

Received: July 7, 2021

Accepted: September 23, 2021

Published: September 26, 2021

Copyright $\odot 2021$ by author(s) and Scientific Research Publishing Inc. This work is licensed under the Creative Commons Attribution International License (CC BY 4.0).

http://creativecommons.org/licenses/by/4.0/

\begin{abstract}
Predictive assessments of the geomorphological systems' behavior under climate warming in southern Siberia have been performed based on time-series data, using theoretical and empirical models of processes. High sensitivity and fast response of erosional, aeolian, and cryogenic processes to current climatic changes are presented. The current trends under changing functioning conditions of geomorphological systems while maintaining climatic trends have been determined. Areas with different targeting of morpholithogenesis are identified.
\end{abstract}

\section{Keywords}

Climatic Trends, Relief Formation Trends, Morphoclimatic Regions, Southern Siberia, Steppes

\section{Introduction}

Global warming impacts the course of many natural processes. Exogenous relief-forming processes are sensitive to climate fluctuations. Therefore, we should expect noticeable changes in morphogenesis in the subarid regions (steppes and forest-steppes) of southern Siberia (Figure 1), which are characterized by unstable natural equilibrium due to the continental climate, relief of mountains and depressions, and location at the southern boundary of the permafrost zone (Bazhenova, 2018). Hence, when solving the issues of rational nature management, we should know the pattern of changes in the intensity and direction of these processes and the functioning of geomorphological systems with fluctuations in climatic parameters, i.e., the forecast of geomorphological research, the methodological basis of which is still poorly developed, become relevant. 


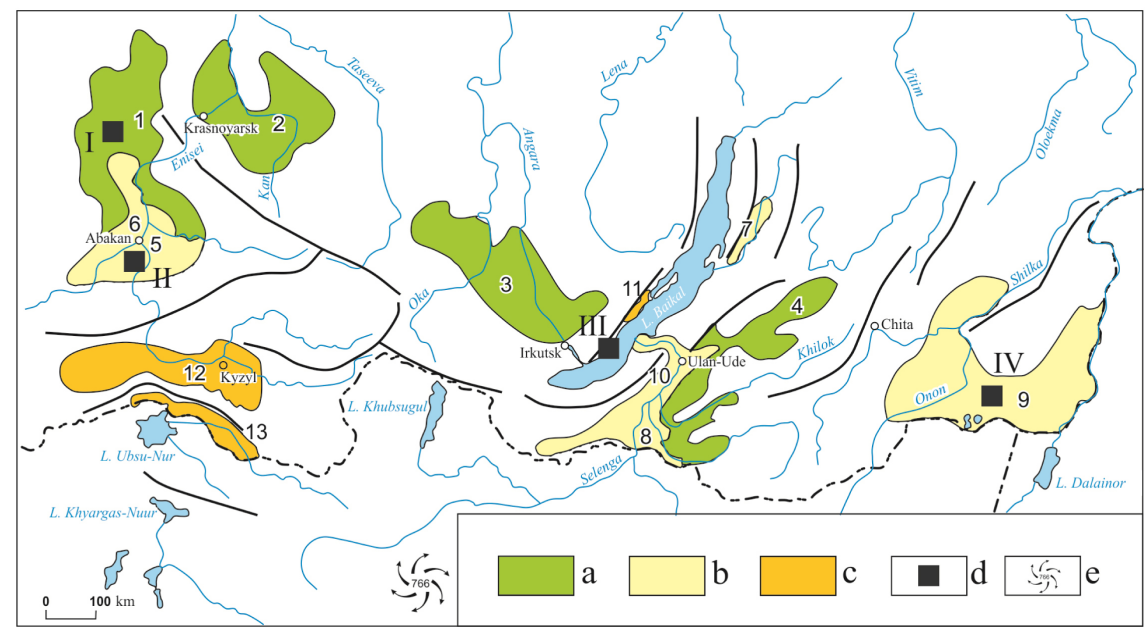

Figure 1. Location of forest-steppe (a), steppe (b) and desert-steppe (c) morphoclimatic regions in southern Siberia: e-complex geographic field stations of the IG SB RAS; e-center of Asian anticyclone. Districts: 1-Nazarovskii, 2-Krasnoyarsk-Kanskii, 3Lena-Angarskii, 4-Selenginskii, 5-Koibalskii, 6-Minusinskii, 7-Barguzinskii, 8Selenga-Khilokskii, 9-Onon-Argunskii, 10-Udinskii, 11-Priolkhonskii, 12-Kyzylskii, 13-Ubsunurskii.

\section{Material and Methods}

Key methods of geomorphological forecasting include extrapolation of tendencies of relief formation (Nazimova et al., 1999), the use of which is possible in the presence of time-series of the intensity rate factors of processes and factors controlling their course. We obtained such a series for the subarid regions of southern Siberia (Bazhenova, 2018; Bazhenova \& Martyanova, 2000), and, thus, analyzed the reaction of the processes to current climatic changes. When identifying tendencies of exogenous relief formation caused by climate change, the main attention was paid to the study of the response to the climatic signal of erosion, aeolian and cryogenic processes.

A number of serious environmental issues are associated with their development in southern Siberia. In the predictive assessment, from a large number of theoretical and empirical models, we selected dependencies in which climatic parameters characterizing the behavior of processes are provided with time series. The validity of their application is confirmed by experimental data from stationary observations. The correlation coefficients of the measured and calculated rates of the processes are quite high (Bazhenova et al., 1997).

To assess the long-term variability of rainfall-runoff, we used the universal equation of soil erosion modified at Moscow University (Litvin, 2002), in which the climatic parameter is represented by the storm rainfall erosion index (the sum of the products of the kinetic energy of rainfall and its maximum intensity). To calculate it, we processed rain pluviograms with a layer of at least $10 \mathrm{~mm}$ for 63 meteorological stations in southern Siberia for 35 - 65 years. The soil loss caused by snowmelt runoff was determined by analyzing the long-term series of water reserves in snow. The long-term dynamics of the suspended sediment 
discharge rate were considered as an integral indicator of time-based changes in the intensity of erosion processes. This method is provided with instrumental observations and is recognized by the majority of domestic and foreign researchers as the most accurate and objective (Gusarov, 2005). When assessing the trends in the development of aeolian processes, data on the number and duration of dust storms were used, the complex climatic deflation index was calculated using the formula from (Wilson \& Cook, 1984), which took into account wind speed, precipitation and air temperature. E. M. Lyubtsova (Bazhenova et al., 1997) tested the using feasibility of this indicator in Siberia.

In assessing the cryogenic processes, the dynamics of depth and rate of seasonal freezing-thawing of soil, changes in the temperature of the soil surface and the upper soil horizons, the number of days with frost at different depths of the annually thawed layer were studied. Calculations of the permafrost degradation rate were made according to the well-known method (Gusarov, 2005), and the probable changes in the rate of soil slow mass displacements-according to the formula in (Devdariani, 1964).

We determined the linear trends of the considered parameters using the least square method to reveal the trends of intensity rate (Simonov, 2005). In most cases, when determining the trends of one or another exogenous process, the timeseries of several stations were used and, not by one parameter, but by several.

\section{Results and Discussion}

Before turning to the assessment results, we should consider the regional features of climatic changes noted in the second half of the $20^{\text {th }}$ century based on time-series analysis (Bazhenova \& Martyanova, 2000). Unidirectional trends of current climatic changes in the study area are clearly traced at the turn of the century between 1978 and 2014 (Bardin et al., 2015). In the island steppes of southern Siberia, in the long-term variation of the mean annual air temperature, there are positive trends that differ only in magnitude. For the period 1966-2001 in the Nazarovskaya and Krasnoyarsk-Kanskaya forest-steppe the value of the linear trend was $0.025^{\circ} \mathrm{C} /$ year, in the Lena-Angarskii region it reached the regional maximum for the forest-steppe 0.064 , and to the east-in the Selenginskaya forest-steppe, the temperature growth rate decelerated to $0.040^{\circ} \mathrm{C} /$ year.

In the steppe regions, the rate of temperature increase during the same period varies from $0.02^{\circ} \mathrm{C}$ to $0.08^{\circ} \mathrm{C} /$ year. Regional assessments reveal the greatest positive trend value in the desertified Kyzylskaya and Barguzinskaya steppes $\left(0.08^{\circ} \mathrm{C} /\right.$ year). An intense temperature change is registered in the Minusinskaya steppes (meteorological stations of Shira, Khakasskaya and Uibat), where the linear trend coefficient has reached $0.06^{\circ} \mathrm{C} /$ year. The next in warming degree are the Udinskaya steppes (Ulan-Ude and Khorinsk), where the linear trend was $0.05^{\circ} \mathrm{C} /$ year. The lowest rate of temperature increase $\left(0.03^{\circ} \mathrm{C} /\right.$ year $)$ was recorded in the easternmost Onon-Argunskaya steppes of Southeastern Transbaikalia (Borzya, Olovyannaya, Priargunsk, Zabaikalsk and Solovievsk). Thus, amid global warm- 
ing, we revealed regional features of the island steppes of Siberia, manifested in a decrease in the rate of growth of the average yearly temperature from west to east between 1966 and 1996. V.A. Obyazov reported (Obyazov, 1999), that in the territory of Southeastern Transbaikalia, temperature changes in the warm period have a negative trend, while cooling in this season is about $0.4^{\circ} \mathrm{C}$ over a century. Only due to the intense increase in temperature during the cold period, the trend of the average annual temperature is positive.

Perennial fluctuations in annual precipitation are not pronounced. Their linear trends are different both in magnitude and in sign, even within individual morphoclimatic regions, which indicates the unstable nature of fluctuations in the humidification of the island steppes. In the forest-steppe complexes of the northwestern part of the belt (Krasnoyarsk-Kanskii and Nazarovskii districts), positive intensity rates of precipitation change were established from 0.15 to 4.1 $\mathrm{mm}$ /year for the period from 1966 to 1996. In the Lena-Angarskii forest-steppe region, the humidity level is mainly decreasing. Negative linear trends in the annual precipitation were most significant at Zima and Khomutovo stations $(-1.6--1.5 \mathrm{~mm} /$ year $)$. These values are the maximum negative values for the study area.

In the Selenginskaya forest-steppe (Bichura and Mukhorshibir), a slight increase in the average annual precipitation in recent decades, with a linear trend coefficient of $0.1-0.2 \mathrm{~mm}$ /year was recorded. In the morphoclimatic region of the Minusinskaya steppe, the character of precipitation fluctuations is also unstable, their linear trend varies from $+0.8 \mathrm{~mm} /$ year (Khakasskaya and Uibat) to $-0.5 \mathrm{~mm}$ /year (Shira). The Koibalskaya foothill-steppe region is characterized by a high intensity of precipitation increase, where the trend was $2.5 \mathrm{~mm} / \mathrm{year}$, i.e., precipitation increased by almost $75 \mathrm{~mm}$ over 30 years.

Assessment of the precipitation trend in the desertified steppe in the Kyzyl region indicates its increased exsiccation over the period under consideration, precipitation here decreased by $30-45 \mathrm{~mm}$. In the Olkhon region, there is a maximum decrease in moisture content; the trend was $-1.17 \mathrm{~mm} /$ year. In the Ubsunurskaya depression, on the contrary, according to (Chistyakov et al., 2009), there is a steady tendency towards an increase in annual precipitation (increasing trend of $78 \mathrm{~mm}$ over the last 100 years), which coincides with powerful secular moisture rhythms and periodically arising twenty and thirty-year precipitation oscillation.

It should be noted that precipitation increased throughout the steppes of Transbaikalia (Western and Eastern), characterized by a trend from 0.1 to 3.3 $\mathrm{mm} /$ year. The only exception was the Selenga-Khilokskii region, where there was a slight decrease in precipitation, estimated by a linear trend coefficient of $0.6 \mathrm{~mm} /$ year. In the Udinskaya dry steppe, precipitation increased at a rate of $0.53 \mathrm{~mm} /$ year. In the Barguzinskaya steppe, humidification remained almost stable, as demonstrated by a slightly positive trend in precipitation $(0.1 \mathrm{~mm} /$ year $)$.

In the Onon-Argunskaya steppe, the most intense increase in moistening was 
observed based upon the trends. The regional trend was recorded at the level of $2.1 \mathrm{~mm} /$ year, i.e., the annual amount increased by $60-65 \mathrm{~mm}$ over the past 30 years, which is about $20 \%$ of their annual amounts. At individual stations, the precipitation growth rates differ significantly. Thus, in the drainless Torey lakes (near Solovievsk), precipitation increased slightly (trend $0.6 \mathrm{~mm} / \mathrm{year}$ ), and according to the data of Zabaikalsk station, the increase in precipitation was estimated by the maximum value of the trend $3.3 \mathrm{~mm} /$ year. An increase in the moisture content of the territory due to increased atmospheric precipitation caused an increase in river discharge and the level of drainless lakes (Obyazov, 1999).

The variability analysis of deflation processes over the past 100 years has revealed a process cyclicity caused by fluctuations in atmospheric moistening. In the longstanding process of dust storms over the last $23-25$ years of the $20^{\text {th }}$ century, contradictory trends of their increase in the eastern part of the island steppes of Siberia and their decrease in the western part were observed (Table 1). They are associated with the change of epochs of atmospheric circulation. The western part of the belt is characterized by short-term fluctuations of small-amplitude deflationary processes. In the eastern regions of the island steppes, longer cycles with a large amplitude are observed, reaching a maximum in Western Transbaikalia. Amid these antiphase fluctuations in the intensity of aeolian processes, characteristic of individual regions, there are general periods of their intensification associated with severe droughts, spreading almost to the entire south of Siberia, when precipitation was $10 \%-20 \%$ (or even more) below normal (in the early 1920s and 1980s). In general, an expansion of the area of a eolian relief formation due to the forest-steppe regions is observed in the south of Siberia (Figure 2).

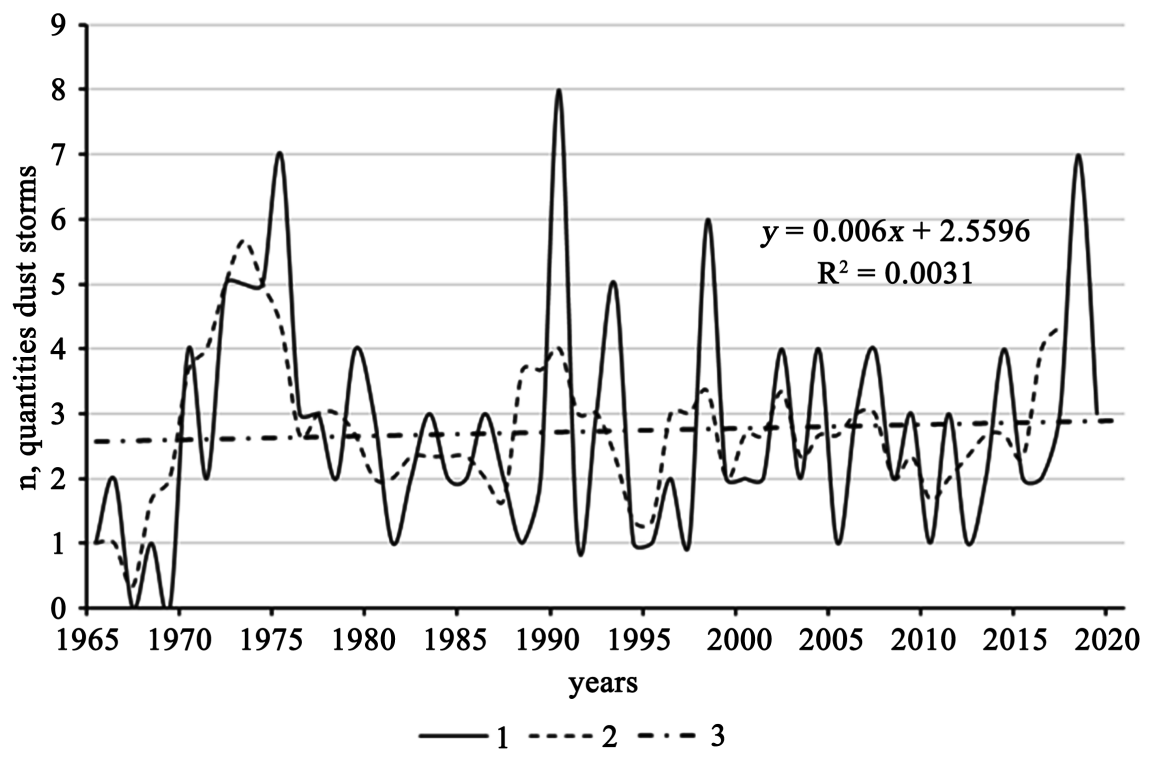

Figure 2. Multi-year trends in the number of dust storms in the Lena-Angarskii foreststeppe region (Irkutsk). 
Table 1. Intensity and tendency of aeolian processes in the south of Siberia.

\begin{tabular}{cccccc}
\hline \multirow{2}{*}{ Location } & Duration of study, years & \multicolumn{4}{c}{ Number of dust storms/year } \\
\cline { 3 - 6 } & 23 & 0.9 & 0 & 5.0 & -0.05 \\
\hline Nazarovo & 23 & 1.4 & 0 & 5.0 & 0 \\
Krasnoyarsk & 23 & 2.2 & 0 & 10.0 & -0.23 \\
Uzhur & 23 & 2.6 & 0 & 8.0 & -0.12 \\
Sharypovo & 23 & 12.7 & 0 & 42.0 & -1.06 \\
Shira & 23 & 11.0 & 0 & 26.0 & -0.47 \\
Khakasskaya & 23 & 13.3 & 0 & 32.0 & +0.22 \\
Beya & 23 & 17.4 & 11 & 29.0 & +0.30 \\
Kyzyl & 23 & 8.1 & 1 & 21.0 & -0.34 \\
Erzin & 26 & 1.2 & 0 & 5.9 & +0.04 \\
Zima & 26 & 1.1 & 0 & 4.2 & +0.07 \\
Zalari & 26 & 2.0 & 0 & 6.4 & +0.02 \\
Cheremkhovo & 26 & 6.0 & 0.2 & 18.2 & -0.12 \\
Angarsk & 26 & 2.5 & 0 & 7.0 & +0.05 \\
Irkutsk & 24 & 5.6 & 0 & 21.0 & +0.17 \\
Ulan-Ude & 23 & 5.0 & 0 & 20.0 & +0.36 \\
Tarbagatai & 23 & 5.1 & 0 & 18.0 & +0.43 \\
Borzya & & & & & \\
\hline & 26 & & & 0.0 & max \\
\hline
\end{tabular}

Based on the statistical analysis of long-term series of observations of the suspended sediment discharge (Table 2), we identified the basins, united into four regions with different trends in the behavior of erosion processes. The prevailing trend in the first $\mathrm{Ob}$-Yenisei region with a positive trend in atmospheric moistening is an increase in the intensity of erosion processes. It is characteristic of $80 \%$ of the area's basins. In the structure of erosion processes, the role of storm runoff increases, which is testified by positive trends in the erosion pluvial index (Table 3).

The intensification of gully formation in the Nazarovskaya, YuzhnoMinusinskaya and Syda-Erbinskaya depressions indicates an increase in the intensity of erosion processes over the past 10 - 15 years (Bazhenova, 2018). Experimental field studies and analysis of aerospace images and large-scale maps for different years show that gullies grow at a particularly fast pace (up to $7 \mathrm{~m}$ per year) in the right-bank forest-steppe regions of depressions. These gully systems pose a significant potential threat to the conservation of the land fund.

The second region (Angara) is distinguished by a complex multidirectional nature of changes in the process intensity. Amid the general downward trend in erosion processes, caused by a negative trend in atmospheric moistening and a decrease in water equivalent of snow cover, a conspicuous intensification of erosion activity is observed in individual river basins, associated with woodland clearance. The strongest influence of clearcuttings on erosion is manifested in felling areas not older than $2-5$ years. If felling areas occupy $1 \%-5 \%$ of the basin area, the suspended sediment discharge rate increases by $50 \%-300 \%$, and 
Table 2. Suspended sediment discharge in southern Siberia.

\begin{tabular}{|c|c|c|c|c|c|c|}
\hline \multirow{2}{*}{ River-locality } & \multirow{2}{*}{$\begin{array}{c}\text { Catchment } \\
\text { area, } \\
\mathrm{km}^{2}\end{array}$} & \multirow{2}{*}{$\begin{array}{c}\text { Duration } \\
\text { of study, } \\
\text { years }\end{array}$} & \multicolumn{4}{|c|}{ Sediment discharge rate, $t / \mathrm{km}^{2}$ per year } \\
\hline & & & medium & $\min$ & $\max$ & trend \\
\hline Biryusa-vil. Shitkino & 24,700 & 40 & 10.2 & 2.5 & 20.8 & +0.07 \\
\hline Vikhoreva-vil. Koblyakovo & 3840 & 29 & 6.6 & 3.1 & 21.3 & -0.13 \\
\hline Iya-Tulun & 14,500 & 38 & 16.1 & 2.2 & 50.6 & +0.46 \\
\hline Uda-vil. Aligdzher & 4980 & 27 & 11.5 & 0.9 & 63.0 & +0.35 \\
\hline Ikei-vil. Ikei & 2400 & 23 & 59 & 1.3 & 21.0 & +0.26 \\
\hline Irkut-vil. Smolenshchina & 14,800 & 38 & 34.3 & 3.2 & 75.3 & -0.99 \\
\hline Olkha-vil. Olkha & 590 & 40 & 2.7 & 0.6 & 13.4 & 0 \\
\hline Chikoi-vil. Gremyachka & 15,600 & 36 & 9.5 & 2.2 & 34.0 & -0.07 \\
\hline Khilok—vil. Khailastui & 38,300 & 38 & 3.3 & 0.5 & 9.5 & -0.01 \\
\hline Uda-Ulan-Ude & 34,700 & 39 & 2.8 & 0.5 & 7.5 & -0.06 \\
\hline Selenga-st. Mostovoi & 440,000 & 44 & 4.6 & 0.8 & 85.2 & -0.06 \\
\hline Barguzin-vil. Barguzin & 19,800 & 46 & 7.5 & 1.8 & 35.2 & -0.10 \\
\hline Onon-vil. Bytev & 49,500 & 24 & 8.5 & 1.4 & 22.5 & +0.02 \\
\hline Shilka-st. Chasovaya & 200,000 & 20 & 14 & 2.7 & 160 & +0.05 \\
\hline
\end{tabular}

Table 3. Changes in the erosion hazard of rainstorms in steppes and forest-steppes of Siberia.

\begin{tabular}{|c|c|c|c|c|c|}
\hline \multirow{2}{*}{ Location } & \multirow{2}{*}{ Duration of study, years } & \multicolumn{4}{|c|}{ Erosional precipitation index } \\
\hline & & medium & $\min$ & $\max$ & trend \\
\hline Achinsk & 30 & 5.9 & 0.1 & 39.4 & +0.10 \\
\hline Krasnoyarsk & 31 & 6.1 & 0.1 & 25.3 & +0.08 \\
\hline Uzhur & 21 & 3.8 & 0.2 & 16.0 & +0.30 \\
\hline Shira & 28 & 4.9 & 1.0 & 24.9 & -0.19 \\
\hline Khakasskaya & 31 & 6.5 & 0.7 & 42.5 & -0.12 \\
\hline Beya & 28 & 5.1 & 1.0 & 19.0 & +0.13 \\
\hline Kyzyl & 26 & 2.1 & 0 & 8.5 & +0.12 \\
\hline Zima & 33 & 3.0 & 0 & 13.6 & +0.03 \\
\hline Balagansk & 28 & 2.5 & 0 & 6.7 & -0.07 \\
\hline Bayandai & 33 & 4.4 & 0 & 14.5 & -0.07 \\
\hline Cheremkhovo & 26 & 3.7 & 0 & 16.1 & -0.08 \\
\hline Khomutovo & 26 & 4.1 & 0.2 & 12.4 & -0.01 \\
\hline Irkutsk & 53 & 7.1 & 0.2 & 23.6 & -0.16 \\
\hline Sarma & 27 & 1.6 & 0 & 5.12 & -0.03 \\
\hline Ulan-Ude & 23 & 3.5 & 0.5 & 11.0 & -0.05 \\
\hline Barguzin & 25 & 4.1 & 0.4 & 14.3 & -0.12 \\
\hline
\end{tabular}


water turbidity by $100 \%-800 \%$ (Burenina \& Onuchin, 1999). Erosion advancing is characteristic of the Educhanka river basin. Currently, felling volume in some areas is increasing.

Erosion advancing is also associated with an increase in the number of wildfires. The new burned-out areas within individual river basins are twice the area of fresh felling. The strongest increase in the intensity of erosion processes is observed in the zone of the Bratsk reservoir's influence within the basins of the Unga, Osa, Zalari, Oka, Belaya and other tributaries of the Angara. The average growth rate of small erosional forms in loess-like loams is $0.2-2.0 \mathrm{~m} /$ year. The latest wave of global warming affected the more frequent periods of low- and high-stand in the reservoir level and the continuing active development of erosion and reformation of the banks, despite the expectation of attenuation of these processes.

In the third region (Selenga), which covers the Barguzin and Selenga basins, a downward trend in suspended sediment discharge prevails. Its underlying cause is a dramatic decline in agricultural activity in this area over the past $20-25$ years. In some areas of Buryatia, with almost complete shutdown of agriculture due to socio-economic reasons, the gully growth rate and the plane erosion rate on slopes decrease (Bazhenova et al., 1997).

The opposite trend-increased intensity of erosion processes is peculiar amid progressive increase in atmospheric moistening in the second half of the $20^{\text {th }}$ century to the fourth region (the upper Amur basin). N. N. Bobrovitskaya highlighted (Bobrovitskaya, 1995) the directed increase in sediment discharge in Transbaikalia in the 1970s-1980s. A dramatic increase in the intensity of gully erosion in the south of Transbaikalia at the end of the $20^{\text {th }}$ century was caused, according to (Golosov et al., 1996), by heavy monsoon rains. Between 1989 and 1991, the annual precipitation depth in the upper reaches of the Onon River increased by $50 \%$ in comparison with the average long-term norm and exceeded $600 \mathrm{~mm}$. This was due to heavy rains $>40 \mathrm{~mm}$ in the summer months, which had not previously been observed within the region. The rapid development of gully erosion in croplands led to a dramatic increase in the number of gullies and the formation of 17 areas of badlands. At the same time, the gully growth rate reached tens, and sometimes hundreds of meters per year (Golosov et al., 1996).

In the south of Siberia, we observe a widespread increase in the soil surface temperature and ground temperature to a depth of $3.2 \mathrm{~m}$. Active degradation of permafrost takes place, which in some regions has different rates (Bazhenova, 2018; Balybina \& Trofimova, 2019). The temperature regime of the seasonally frozen soils of the forest-steppes in Priangarye varies most intensively with a positive average annual soil temperature. In the areas of insular permafrost development with a negative mean annual temperature of the soil surface (Bayandai station $-1.1^{\circ} \mathrm{C}$ ), warming processes are slower (Bazhenova, 2018). Numerous new thermokarst funnels in the valleys of the Unga, Zalari, Oka, Kitoi, Irkut, Typta, Bayandayka rivers (Priangarye) and in the valleys of Transbaikalia, serve 
as an indicator of the permafrost degradation processes in the subarid landscapes of southern Siberia (Figure 3).

Against the background of global warming in the steppes and forest-steppes of Siberia, there is a slight decrease in the climate continentality. Climatic changes cause changes in the functioning of geomorphological systems. The availability of experimental and calculated data on the behavior of geomorphological processes in the island steppes of southern Siberia allows us to consider the possible directions of transformation of the modes of their functioning under the regional climate changes. The results of the trend calculations are summarized in Table 4, which characterizes the sensitivity of various zonal-sector types of morphodynamic systems to climatic fluctuations.

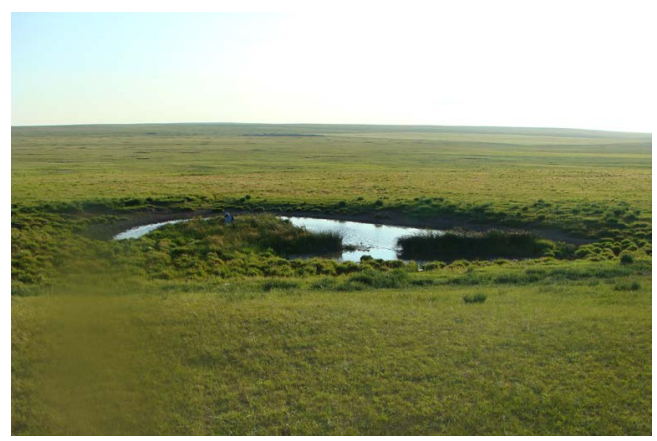

Figure 3. Thermokarst funnel in the bottom of a temporary watercourse (Onon-Argunskaya steppe, Ary-Bulak pad), 2015. Photo by O. I. Bazhenova.

Table 4. Changes in exogenous processes due to climatic trends.

\begin{tabular}{cccccccc}
\hline \multirow{2}{*}{$\begin{array}{c}\text { Morphoclimatic Climatic trends } \\
\text { region }\end{array}$} & \begin{tabular}{c} 
Mean annual \\
temperature, \\
\cline { 2 - 7 } \\
${ }^{\circ}$ C/year
\end{tabular} & $\begin{array}{c}\text { Annual } \\
\text { precipitation } \\
\text { mm }\end{array}$ & $\begin{array}{c}\text { Basin } \\
\text { erosion }\end{array}$ & $\begin{array}{c}\text { Slope } \\
\text { storm } \\
\text { washout }\end{array}$ & Nivation Defluction & $\begin{array}{c}\text { Aeolian } \\
\text { (dust) } \\
\text { storms }\end{array}$ \\
\hline Nazarovskii & 0.025 & 1.06 & + & + & 0 & + & - \\
Krasnoyarsk-Kanskii & 0.025 & 0.13 & + & + & 0 & - & - \\
Lena-Angarskii & 0.064 & -0.95 & - & 0 & - & - & + \\
Selenginskii & 0.04 & 0.15 & - & - & 0 & - & + \\
Koibalskii & 0.05 & 2.50 & + & + & + & + & + \\
Minusinskii & 0.06 & 1.14 & + & - & 0 & 0 & - \\
Barguzinskii & 0.08 & 0.09 & - & - & 0 & 0 & - \\
Selenga-Khilokskii & 0.05 & -0.55 & - & - & 0 & - & 0 \\
Onon-Argunskii & 0.03 & 2.13 & + & + & + & + & + \\
Udinskii & 0.05 & 0.53 & - & 0 & 0 & 0 & 0 \\
Priolkhonskii & 0.04 & -1.17 & - & - & - & - & + \\
Kyzylskii & 0.08 & -0.99 & - & + & 0 & - & + \\
Ubsunurskii & 0.05 & 0.49 & & + & + & - & - \\
\hline
\end{tabular}

a. "+"-increasing intensity of processes; "0"-no change; "dash"-decreasing intensity. 
When analyzing trends, we took into account that each type of system differs in its "starting" (basic) modes of functioning (Figure 4).

Further transformation of the modes of exogenous relief formation occurs depending on this basic level, the sensitivity of systems to climatic fluctuations and the nature of the climatic signal (the ratio of heat and moisture trends). Foothill-steppe systems (Koibalskaya steppe), Central Asian steppe, transitional

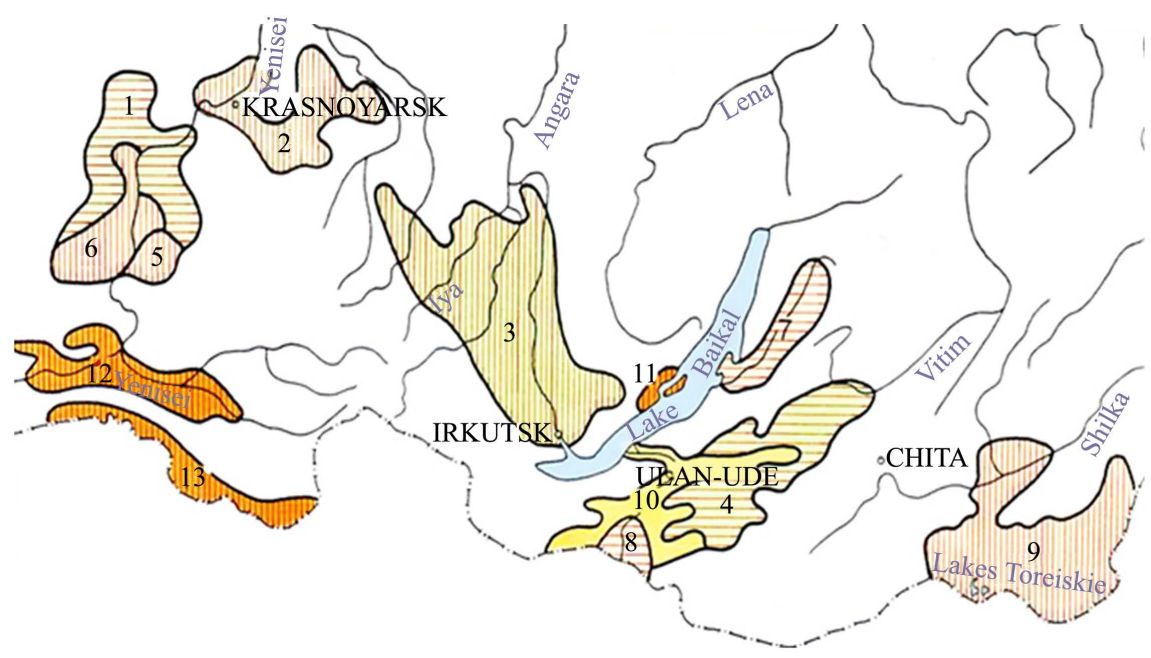

(A)

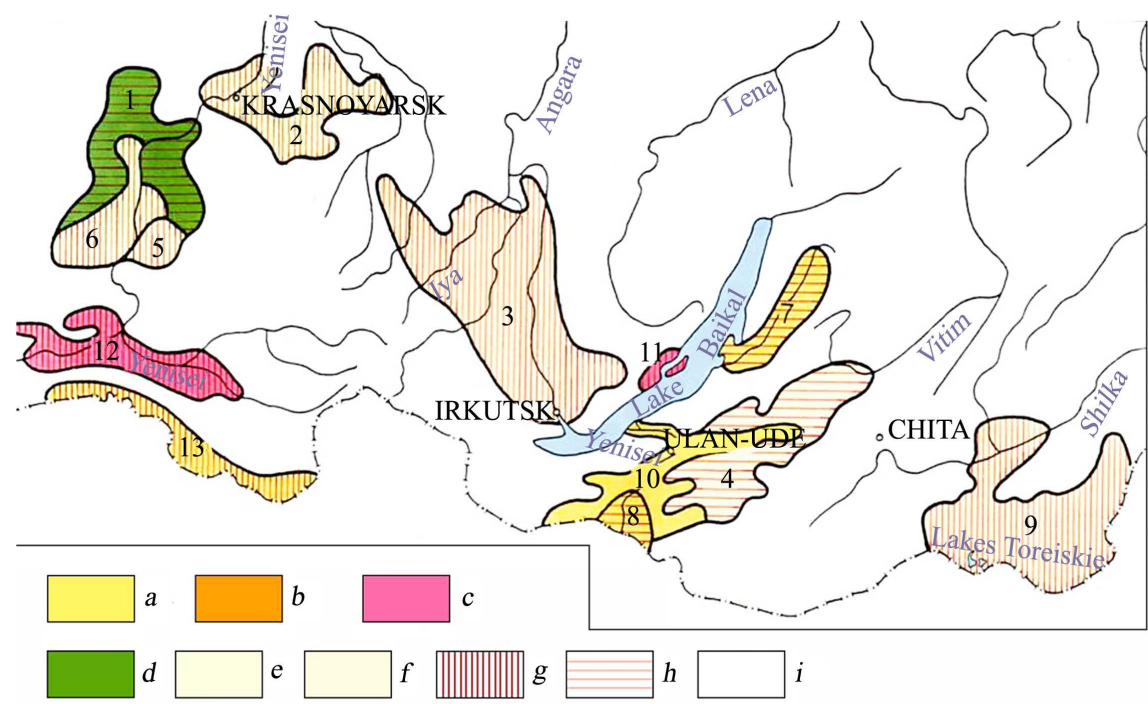

(B)

Figure 4. Basic (up to 1980) modes of functioning of denudation systems in the island steppes of southern Siberia (A) and their probable changes while maintaining modern climatic trends (B). Regimes: $\mathrm{a}-$ dry steppe, $\mathrm{b}-$ desertified, $\mathrm{c}-$ semi-desert, $\mathrm{d}-$ subtaiga, $\mathrm{e}-$ forest-steppe, $\mathrm{f}-$ steppe. Intensity of morphogenesis: $\mathrm{g}$-increase, $\mathrm{h}$-decrease, and i-no change. 1-13 morphoclimatic regions. Location of forest-steppe (a), steppe (b) and desert-steppe (c) morphoclimatic regions in southern Siberia: $\mathrm{d}-$ complex geographic stations of the IG SB RAS; e-center of the Asian anticyclone. Districts: 1-Nazarovskii, 2-Krasnoyarsk-Kanskii, 3-Lena-Angarskii, 4-Selenginskii, 5-Koibalskii, 6-Minusinskii, 7-Barguzinskii, 8-Selenga-Khilokskii, 9-Onon-Argunskii, 10-Udinskii, 11-Priol'khonskii, 12-Kyzylskii, 13-Ubsunurskii. 
forest-steppe and desert-steppe systems are the most sensitive, where more than $75 \%$ of the analyzed parameters undergo changes. Weak sensitivity to the ongoing climatic changes is characteristic of the dry steppe systems of the Udinskii district, formed on a thick sandy lithogenic base (less than $25 \%$ of the analyzed parameters change). Other types of systems have average sensitivity.

Moisture acts as a limiting factor in changing the modes of functioning of the systems. In areas with high growth rates of atmospheric humidification, the energy base of relief formation increases, and positive trends in exogenous processes are observed. Such a saturated zone type of transformation of the modes of functioning is characteristic of the Koibalskii, Onon-Argunskii and Nazarovskii districts.

If the current climatic trend (increasing atmospheric moistening) continued in the Koibalskaya foothill steppe, taking into account its basic regimes, we should expect the development of processes inherent in forest-steppe. In recent years (2013-2020), moist (total precipitation more than $600 \mathrm{~mm} /$ year) and relatively warm (mean annual temperature $+2.1^{\circ} \mathrm{C}-3.9^{\circ} \mathrm{C}$ ) conditions for the functioning of geosystems have also been observed here. There were no heavy showers during this period. As a result, small erosional forms began to overgrow. In addition, abandoned arable land began to overgrow with small-leaved elm. This phenomenon is typical for different regions of the South-Minusinsk depression. Overgrown fields are found along the road from Sayanogorsk to Abakan and from Abakan to Shira. Active overgrowing of fields is also observed around the key site of the Novonikolaevskii field station (Figure 5).

In the Nazarovskaya forest-steppe, the role of slow massive ground movements (creep), landslide and landslide-talus processes, as well as fluvial activity will increase, i.e., the processes characteristic of subtaiga will develop. The

1

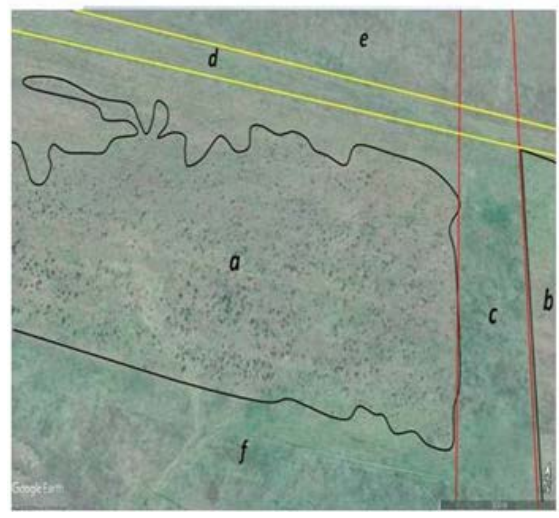

2

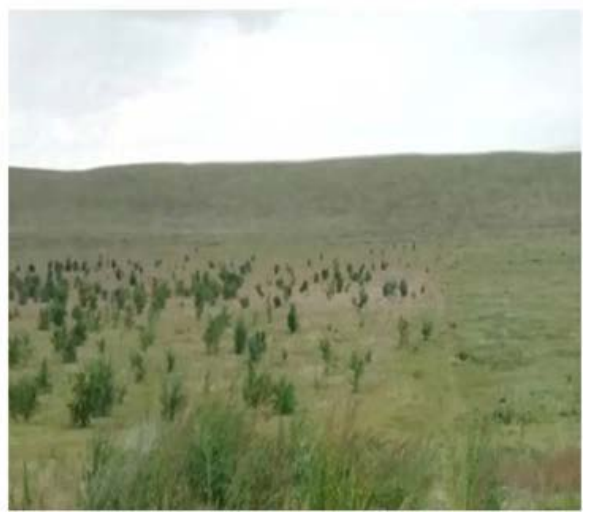

Figure 5. Overgrowing of fields in the Koibalskaya steppe. 1-section of the inter-ridge topographic low near the village of Novonikolaevka: Field overgrown with elm (dark green dots) (a), field without shrubs (b), the bottom of the blind creek (transect key site of the Novonikolaevskii physical-geographical field station) (c), road (d), southern slope of the northern ridge (e), northern slope of the southern ridge (f) (Google Earth image, 2021). Coordinates: N530 $11^{\prime} 24^{\prime \prime}$ E E910 14'36". 2-identic area, August 22, 2020. Photo by E. M. Tyumentseva. 
tendency for a moisture reduction is currently well manifested in the LenaAngarskii forest-steppe region, in which the role of aeolian material migration increases, in the Selenga-Khilok steppe, as well as in the desertified steppes of Tuva and Olkhon region, where the transformation of exogenous regimes proceeds according to the arid type. The increased pace of warming, combined with a gradual decrease in precipitation, as well as with anthropogenic xeromorphization and degradation of soil and vegetation cover, will contribute to the expansion of areas with dry steppe morphogenesis (Barguzinskii, Udinskii, Ubsunurskii and Selenga-Khilok districts). In the Kyzylskii and Olkhonskii districts, current climatic trends entail the occurrence of semi-desert type of morphogenesis.

\section{Conclusion}

Erosion, aeolian, and cryogenic processes in subarid landscapes are therefore highly sensitive and responsive to climate warming. Aeolian material migration increases, whilst the intensity of erosion processes decreases. In the northwestern part of the belt, these trends are reversed. The transition zone, experiencing changes in the direction of morphogenesis, is distinguished by the greatest stability with a small value of climatic and geomorphological trends. In general, diversity and contrast of the modes of exogenous relief formation increase under the influence of recent regional climate changes in the island steppes of southern Siberia. In accordance with forecasts of further climate warming in the south of Siberia in the $21^{\text {st }}$ century (Izrael' et al., 1999), it should be expected that the identified trends would continue here in the future (Grechishchev, 1997). The forecast of changes in zonal landscape conditions was made according to climate characteristics based on neural network technology. It indicates that in the south of Central Siberia, with an increase in summer temperatures by $1^{\circ} \mathrm{C}-2^{\circ} \mathrm{C}$, and winter temperatures by $3^{\circ} \mathrm{C}-4^{\circ} \mathrm{C}$ a loss of forest cover is expected on the southern edge of the boreal region, even if an increase in annual precipitation amounts by $30-50 \mathrm{~mm}$ (Nazimova et al., 1999). Moreover, the climatic conditions of the future will contribute to the advancement of forest steppes to the north and east, and of the steppes to the north and south to modern semi-deserts (Kobak \& Kondrasheva, 2000). In this regard, not only further changes in the intensity of soil erosion and deflation processes arise but also the expansion of the area of their development, which should be taken into account when planning environmental management.

\section{Acknowledgements}

The study was done at the expense of the state assignment of the RF (No. AAAA-A21-121012190017-5).

\section{Conflicts of Interest}

The authors declare no conflicts of interest regarding the publication of this paper. 


\section{References}

Balybina, A. S., \& Trofimova, I. E. (2019). Soil Temperature Dynamics in Transbaikalia under Climate Change Conditions. Russian Meteorology and Hydrology, 44, 109-116. https://doi.org/10.3103/S1068373919100108

Bardin, M. Y., Platova, T. V., \& Samokhina, O. F. (2015). Features of the Observed Climate Changes in the Territory of Northern Eurasia According to Regular Monitoring Data and Their Possible Factors. Proceedings of the Hydrometeorological Research Center of the Russian Federation, 358, 13-35.

Bazhenova, O. I. (2018). Current Denudation of the Foothill Steppe Plains of Siberia. GEO. https://doi.org/10.21782/B978-5-6041445-2-7

Bazhenova, O. I., \& Martyanova, G. N. (2000). Response of Steppe and Forest-steppe Morphodynamic Systems to Current Climate Change. Geography and Natural Resources, 4, 23-32.

Bazhenova, O. I., Lyubtsova, E. M., Ryzhov, Yu. V., \& Makarov, S. A. (1997). SpatioTemporal Analysis of the Dynamics of Erosion Processes in the South of Eastern Siberia. Nauka.

Bobrovitskaya, N. N. (1995). Water Erosion on Slopes and River Sediment Runoff. Ph.D. Thesis, Geological and Geographical Institute (GGI).

Burenina, T. A., \& Onuchin, A. A. (1999). Runoff Dynamics in the Watersheds of the Northern Angara Region in Connection with Cuttings and Wildfires. Geography and Natural Resources, 2, 42-46.

Chistyakov, K. V., Moskalenko, I. G., \& Zelepukina, E. S. (2009). Climate of the Ubsunur Depression: A Spatial Model. Izvestia RGO, 141, 44-61.

Devdariani, A. S. (1964). Measurement of Displacements of the Earth's Surface. Nauka.

Golosov, V. N., Kozlovskaya, M. E., \& Patsukevich, Z. V. (1996). Specificity of Erosion Processes in Southwest Transbaikalia. Vestnik Moskovskogo Universiteta. Seria 5. Geografia, 4, 91-97.

Grechishchev, S. E. (1997). Forecast of Thawing and Distribution of Permafrost and Changes in Cryogenic Cracking of Soil in Russia under Climate Warming. Earth's Cryosphere, 1, 59-65.

Gusarov, A. V. (2005). The Tendencies of Erosion and Suspended Sediment Yield Changes on the Earth during the Second Half of 20th Century. Ph.D. Thesis, Kazan (Volga Region) Federal University.

Izrael', Y. A., Pavlov, A. V., \& Anokhin, Y. A. (1999). Analysis of Recent and Expected Changes in Climate and Permafrost Zone in Northern Regions of Russia. Russian Meteorology and Hydrology, 3, 18-27.

Kobak, K. I., \& Kondrasheva, N. Yu. (2000). Possible Changes in the Size of the Steppe Zone of Russia Under the Global Warming in the 21st Century. In K. Botanical (Ed.), Proceedings of Modern Problems of Botanical Geography, Cartography, Geobotany, Ecology (pp.170-171). Komarov Botanical Institute of RAS.

Litvin, L. F. (2002). Geography of Erosion of Agricultural Lands. Akademkniga.

Nazimova, D. I., Nozhenkova, L. F., \& Pogrebnaya, N. A. (1999). Application of Neuronet Technologies for Classification and Prediction of Zonal Conditions of Landscapes by Climate Indications. Geography and Natural Resources, 2, 117-122.

Obyazov, V. A. (1999). Secular Tendencies of Climate Change in the Southeast of Transbaikalia and in Adjacent Regions of China and Mongolia. Russian Meteorology and 
Hydrology, 10, 33-40.

Simonov, Y. G. (2005). Methodological Problems of Modern Geomorphology. In Proceedings of New and Traditional Ideas in Geomorphology: 5th Shchukin Conf. (pp. 28-380). Publishing House of Moscow University.

Wilson, S. J., \& Cook, R. W. (1984). Wind Erosion. Soil Erosion. Kolos. 